\title{
Öğretmen Adaylarının Toplumsal Cinsiyet Algılarına Göre Okul Öncesi Öğretmenliğine İlişkin Görüşleri ${ }^{1}$
}

\author{
DOI: $10.26466 /$ opus.516102 \\ * \\ $\underline{\text { Sema Öngören* }}$
}

* Dr. Öğr. Üyesi Nevşehir Hacı Bektaş Veli Üniversitesi, Eğitim Fakültesi, Nevşehir/ Türkiye E-Posta: ongorensema@gmail.com

ORCID: $\underline{0000-0002-6034-1400}$

Öz

Öğretmenlik mesleği tercihlerinde toplumsal cinsiyet algisının önemli bir etken olduğu günümüzde özellikle okul öncesi öğretmenliği gibi kadınlar için daha uygun görülen bir alanda eğitim alan kadın ve erkek öğretmen adaylarının toplumsal cinsiyete duyarl olarak yetişmeleri ve mesleklerine karşı olumlu bir algıya sahip olmaları nitelikli bir öğretmen olmanın ilk adımı olarak düşünülebilir. Bu araştırma, öğretmen adaylarının toplumsal cinsiyet algılarına göre okul öncesi öğretmenliğine ilişkin görüşlerini incelemek amacıyla yapılmıştır. Araştırma nitel araştırma yöntemlerinden durum çalışması desenine uygun olarak yürütülmüştür. Araştırmanın çalışma grubunu Nevşehir Hacı Bektaş Veli Üniversitesi Okul Öncesi Eğitimi ABD lisans programında öğrenim gören 105 öğretmen adayı oluşturmuştur. Araştırmanın verileri, araştırmacı tarafından geliştirilen yarı yapılandırılmış görüşme formu ile toplanmış ve elde edilen veriler içerik analizi yöntemiyle analiz edilmiştir. Araştırma sonucunda okul öncesi öğretmen adaylarının okul öncesi öğretmenlik mesleği ile ilgili bazı cinsiyetçi kalıp yargılara sahip olmakla birlikte, genel olarak bu meslek ile ilgili olumlu bir yaklaşıma sahip oldukları belirlenmiştir. Araştırmada elde edilen sonuçlar doğrultusunda, öğretmen adaylarının mesleklerine karşı pozitif cinsiyet algısı oluşturabilmeleri için gerekli çalışmaların yapılması önerilmektedir.

Anahtar Kelimeler: Öğretmen adayı, Toplumsal cinsiyet, Okul öncesi öğretmenliği

\footnotetext{
${ }^{1}$ Bu çalışma, IV. International Academic Research Congress'de (INES, 30 Ekim- 03 Kasım 2018- AlanyaTürkiye) sözlü bildiri olarak sunulmuştur.
} 


\title{
Teacher Candidates' Views on Preschool Teaching According to Social Gender Perceptions
}

\begin{abstract}
It is the first step of being a qualified teacher when it comes to gender-perception in teaching professions, and it is especially important for women such as preschool teachers to be trained in a field that is more suitable for women. This research has been conducted to examine the opinions of teacher candidates on preschool teaching profession according to gender perceptions. The research was done by the case study pattern, one of the qualitative research methods. The study group consisted of 105 teacher candidates studying at Pre-School Education Department in Nevsehir Hacı Bektas Veli University. The data of the study was collected by semi-structured interview from developed by the researcher, and the obtained data were analyzed by content analysis method. As a result, it was determined that pre-school teacher candidates have some gendered stereotypes about the preschool teaching profession; however, they generally have a positive approach related to this profession. In light of the results obtained in the study, it is suggested that the necessary studies should be carried out to enable the pre-school teachers to create a positive gender perception.
\end{abstract}

Keywords: $\quad$ Teacher candidate, Gender, Pre-school teaching 


\section{Giriş}

Cinsiyet, erkek ve dişi olmanın biyolojik yönünü anlatmak için kullanılır (Bee ve Boyd, 2009). Cinsiyet rolleri, kadınların ve erkeklerin nasıl düşünmesi, hareket etmesi ve hissetmesi gerektiğine dair beklenti kümeleridir (Santrock, 2012). Başka bir deyişle bir kültürde kadın yada erkek olmaya uygun görülen davranış, tutum, hak, görev ve yükümlülükler kümesidir (Bee ve Boyd, 2009). Toplumsal cinsiyet ise cinsiyetin toplumsal ve psikolojik yönlerine işaret eder. Kadın ve erkek olarak toplumun bizi nasıl gördüğü, nasıl algıladığı, nasıl düşündüğü ve nasıl davranmamızı beklediği ile ilgili bir kavram olan toplumsal cinsiyet (Altınova ve Duyan, 2013) aynı zamanda kişinin kendisini kadın yada erkek olarak tanımlamasidır (Woolfolk-Hoy, 2015).

Bireyler doğdukları andan itibaren kız yada erkek olarak davranmaya yönelik olarak sosyalleştirilirler (Trawick-Smith, 2014) ve kendi kültürlerinde cinsiyetlerine uygun görülen davranışlarla tutarlı bir toplumsal cinsiyet duygusu ile büyürler (Bee ve Boyd, 2009). Doğuştan gelen bu biyolojik farklılıklar kültürel olarak yorumlanıp değerlendirilir. Bireylerin cinsiyetlerine göre nasıl davranması gerektiği, neyin erkeksi ve neyin kadınsı olduğu ile ilgili toplumsal beklentiler geliştirilmiştir (Bee ve Boyd, 2009; Woolfolk-Hoy, 2015). Böylece kadınlar ve erkeklerin hangi davranış ve faaliyetleri yapabileceklerine, hangi haklara ve güce kimin ne derece sahip olduğuna veya sahip olması gerektiğine ilişkin toplumsal beklentilere uygun davranması beklenir (Dökmen, 2009). Bu beklentiler, toplumdan topluma ve aynı toplum içinde bir toplumsal kesimden diğerine kısmen değişir (Altınova ve Duyan, 2013).

Bütün toplumlarda erkek ve kadın rollerine uygun görülen bir dizi davranış, tutum, hak, görev ve yükümlülükler söz konusudur (Bee ve Boyd, 2009). Kadınların daha duyarlı, ilgili ve bakım verici vb. olarak algılanmaları; ev kadını, öğretmen, hemşire vb. olmalarının beklenmesi, erkeklerin bağımsız, atılgan, kuvvetli vb. algılanmaları; asker, mühendis, tüccar vb. olmalarının beklenmesi toplumsal cinsiyet farklılıklarından kaynaklanmaktadır (Dökmen, 2009). Bu nedenle toplumsal cinsiyet ayrımları hem kadınların hem de erkeklerin yaşamını şekillendirir ve sonuçta bu çeşitlilik sadece farklılıktan daha fazla anlam taşır (Altınova ve Duyan, 2013; Dökmen, 2009). 
Toplumsal tabakalaşma bağlamında toplumsal cinsiyete dayalı beklentiler Türkiye'de kadını erkeklere göre daha dezavantajlı bir konuma sokmakta, kadınlar kendilerine biçilen cinsiyet rolleri nedeniyle ekonomik ve sosyal hayattta önemli sorunlarla karşılaşmaktadırlar. Üniversite mezunu kadınlar arasında bile çalışma, kariyer edinme, kendi ayakları üzerinde durma anlayışı yerine uygun bir eş bulup evinin kadını olma düşüncesi önemli bir yer tutmakta, kadınlar çalışma hayatındaki zorlu rekabet yerine ev hayatının rahatlı̆ııı tercih etmektedirler (Zencirkıran, 2016). Bunun yanında günlük yaşamda bir dereceye kadar değişmiş olsa da meslek tercihlerinde, boş zaman aktivitelerinde, medyadaki karakterlerde kalıplaşmış cinsiyet rollerinin pek çok örneği sergilenmeye devam etmektedir. Örneğin günümüz TV programları geçmişe oranla daha çok kariyer odaklı kadın içerse de kadın karakterler genç, çekici, şefkatli, duygusal ve mağdur olmaya devam etmektedir. Buna karşın erkek karakterler genellikle baskın ve güçlüdür (Berk, 2013).

Cinsiyetler arası farklılaştırma \ayırım, erkekler ve kadınların özellikleri hakkında paylaşılan kalıp yargılardır. Bu kalıp yargılar erkekler yüksek statülü rollerle, kadınlar ise aile içi ve düşük statülü rollerle karakterize edildiklerinde erkeği güçlendirmeye ve onun iktidarını sürdürmeye yardım eder (Ayan, 2014). Bireyin diğer insanlarla olan ilişkilerindeki alg1 ve beklentilerini yönlendiren en önemli etkenlerden olan cinsiyet kalıp yargıları da belli beklentilere neden olmakta ve bireylerin performansları bu beklentilere göre değerlendirilmektedir (Özyurt, 2014). Dolayısıyla bir toplumda kadın ve erkeklerin toplumsal hayata katılım biçimi, oranı, temsili, görünürlüğü ve mesleki tercihleri önemli oranda o toplumda geçerli olan toplumsal cinsiyet algısından etkilenmektedir (Öngen ve Aytaç, 2013).

Bireyin yaşamını biçimlendiren en önemli olgulardan birisi meslek tercihidir (Bozdoğan, Aydın ve Yıldırım, 2007). Bireyler meslekleri yolu ile bir noktada kendilerini gerçekleştirmektedirler. Kişinin mesleğinin, yetenek ve ilgilerine uygun olması onun kişilik gelişimini ve toplumsal uyumunun sağlıklı olması olarak da değerlendirilebilir (Üstün, Erkan ve Akman, 2004). Öğretme-öğrenme çabasının bir uğraş alanı olarak çok eski bir geçmişe sahip olan; biyolojik, psikolojik ve sosyokültürel bir varlık olan bireyleri yetiştirme ve kültürel mirası gelecek nesillere aktarmada önemli görev ve sorumlulukları bulunan öğretmenlik mesleği tercihleride 
bu bağlamda hem bireysel hemde toplumsal açıdan önem arz etmektedir (Coştu, 2011). Eğitim-öğretim faaliyetlerinin istenilen amaca ulaşabilmesinde ve öğrencilerin istenilen davranışları kazanmalarında en önemli unsurlardan biri öğretmendir. Öğretmen, öğrenmeye rehberlik eden, öğrencide anlamlı öğrenmeyi sağlayan kişidir (Aktürk, 2012). Nitelikli insan gücünün yetiştirilmesi ve bireylerin sosyalleşmesinde etkin bir rol alan öğretmen adaylarının tercih ettikleri mesleklerine karşı olumlu bir tutum sergilemesi ve mesleklerini severek yapmaları önem arz etmektedir (Kızıltaş, Halmatov ve Sarıçam, 2012).

Alan yazında öğretmen adaylarının öğretmenlik mesleğine yönelik tutumlarına (Aktürk, 2012; Aslan ve Akyol, 2006; Ayık ve Ataş, 2014; Balat, Bilgin ve Ünsal, 2017; Durmuşçelebi, Yıldız ve Saygı, 2017; ) ve öğretmenlik mesleğini tercih etme nedenlerine (Aksu, 2016; Çetin, 2012; Çermik, Doğan ve Şahin, 2010; Ekinci, 2017; Özbek, Kahyaoğlu ve Özgen 2007; ) ilişkin çeşitli çalışmalar mevcuttur. Yapılan araştırmalarda (Johnston ve diğerleri 1999; Mulholland ve Hansen, 2003; Saban, 2003; Smedley, 2007; Terzi ve Tezci, Güz 2007; Ekici, 2014; Gökçe ve Sezer, 2012; Durmuşçelebi, Yıldız ve Saygı, 2017) öğretmenlik mesleği tercihlerinde cinsiyetin önemli bir faktör olduğu, öğretmenlik mesleğinin daha çok kadın adaylar tarafından tercih edildiği ortaya konulmuştur. Öğretmenlik mesleği tercihlerinde toplumsal cinsiyet algısının önemli bir etken olduğu günümüzde özellikle okul öncesi öğretmenliği gibi kadınlar için daha uygun bulunan bir alanda eğitim alan kadın ve erkek öğretmen adaylarının toplumsal cinsiyete duyarlı olarak yetişmeleri ve mesleklerine karşı olumlu bir algıya sahip olmaları nitelikli bir öğretmen olmanın ilk adımı olarak düşünülebilir. Bu araştırmada, öğretmen adaylarının toplumsal cinsiyet algılarına göre okul öncesi öğretmenlik mesleğine ilişkin görüşlerini incelemek amacıyla yapılmıştır. Bu doğrultuda araştırmanın alt amaçları öğretmen adaylarının; okul öncesi öğretmenlik mesleğini tercih etme nedenleri, okul öncesi öğretmenlik mesleğinin kadınlar ve erkekler açısından avantajları ve dezavantajları, okul öncesi eğitimde öğretmenin cinsiyetinin mesleki yeterliliğe etkisi, toplumsal cinsiyet açısından toplumun okul öncesi öğretmenliğine bakış açısı ve toplumsal cinsiyet algılarına göre okul öncesi öğretmenlik mesleğinin kendilerine uygunluğuna ilişkin görüşlerini incelemek olarak belirlenmiştir. 


\section{Yöntem}

Araştırma nitel araştırma yöntemlerinden durum çalışması desenine uygun olarak yürütülmüştür.

\section{Çalışma Grubu}

Araştırmanın çalışma grubunu, Nevşehir Hacı Bektaş Veli Üniversitesi Eğitim Fakültesi Okul Öncesi Eğitimi Anabilim Dalında öğrenim gören 105 öğretmen adayı oluşturulmuştur. Öğretmen adaylarına ilişkin bilgiler Tablo 1'de sunulmuştur.

Tablo 1. Öğretmen adaylarına ilişkin kişisel bilgiler

\begin{tabular}{llll}
\hline Değişken & Düzey & f & $\mathbf{\%}$ \\
\hline Cinsiyet & Kadın & 90 & 85.7 \\
& Erkek & 15 & 14.3 \\
\hline Yaş & $18-20$ & 80 & 80 \\
& $21-25$ & 17 & 17 \\
& $26-30$ & 2 & 2 \\
& $31-+$ & 1 & 1 \\
\hline Mezun olunan & Anadolu Lisesi & 52 & 51 \\
lise türü & Meslek Lisesi & 25 & 24.5 \\
& İmam Hatip Lisesi & 14 & 13.7 \\
& Düz Lise/Temel Lise & 5 & 4.9 \\
& Anadolu Öğretmen Lisesi & 3 & 2.9 \\
& Açı öğretim & 2 & 2 \\
& Fen Lisesi & 1 & 0.9 \\
\hline
\end{tabular}

Tablo 1 incelendiğinde, öğretmen adaylarının çoğunun cinsiyetinin kadın (\%85.7) olduğu, \%80'inin 18 ile 20 yaş aralığında yer aldığı görülmektedir. Mezun oldukları okul türlerine bakıldığında birinci sırada Anadolu Lisesi (\%51) yer alırken, son sırada Fen Lisesi (\%0.9) yer almıştır.

\section{Verilerin Toplanması}

Araştırma verilerinin toplanmasında araştırmacı tarafından uzman görüşleri doğrultusunda geliştirilen ve yedi açık uçlu sorudan oluşan yarı yapılandırılmış görüşme formu kullanılmıştır. Görüşme formunda kişisel 
bilgilerin yanında, öğretmen adaylarının; okul öncesi öğretmenlik mesleğini tercih etme nedenleri, okul öncesi öğretmenlik mesleğinin kadınlar ve erkekler açısından avantajları ve dezavantajları, okul öncesi eğitimde öğretmenin cinsiyetinin mesleki yeterliliğe etkisi, toplumsal cinsiyet açısından toplumun okul öncesi öğretmenliğine bakış açısı ve toplumsal cinsiyet algılarına göre okul öncesi öğretmenlik mesleğinin kendilerine uygunluğuna ilişkin görüşlerini belirlemeye yönelik sorular yer almıştır. Görüşme formu hazırlanırken literatür taraması yapılarak ilgili araştırmalarda yer alan görüşme soruları incelenmiş ve görüşme formu oluşturulmuştur (Yalçın, Yalçın ve Macun, 2017; Esen, 2013; Kızıltaş, Halmatov ve Sarıçam, 2012). Görüşme formunda yer alan soruların anlaşılabilir ve esnek olmasına dikkat edilmiş ve uzman görüşlerine başvurularak gerekli düzenlemeler yapılmıştır.

\section{Verilerin Analizi}

Görüşme formundan elde edilen verilerin analizinde içerik analizi yöntemi kullanılmıştır. Analiz sonucunda elde edilen benzer kodlar temalar altında toplanmış ve veriler sayısal hale getirilerek sunulmuştur. Öğretmen adaylarından bazıları soruların tamamına yanıt vermemiş ve değerlendirme işlemleri sadece o soruya verilen cevaplar dikkate alınarak gerçekleştirilmiştir. Verilerin analizinde gerçekleştirilen kodlamanın güvenirliğini sağlamak için görüşme formlar iki araştırmacı tarafından ayrı ayrı kodlanmıştır ve elde edilen temalar yorumlanırken doğrudan alıntılara yer verilmiştir.

\section{Bulgular}

Bu bölümde öğretmen adaylarının toplumsal cinsiyet algılarına göre okul öncesi öğretmenlik mesleğine yönelik görüşlerine ilişkin bulgular frekans değerleri ile birlikte tablolar halinde sunulmuştur. 


\section{Öğretmen Adaylarının Okul Öncesi Öğretmenlik Mesleğini Tercih Etme Nedenleri}

Öğretmen adaylarının okul öncesi öğretmenlik mesleğini tercih etme nedenlerine ilişkin bulgular içsel ve dışsal nedenler olarak iki kategoriye ayrılmış ve Tablo 2 'de verilmiştir.

Tablo 2. Öğretmen adaylarının okul öncesi öğretmenlik mesleğini tercih etme nedenleri

\begin{tabular}{|c|c|c|}
\hline Nedenler & $\mathbf{f}$ & Öğretmen Adaylarının Görüşleri \\
\hline İçsel & 89 & \\
\hline Çocukları sevmek & 25 & Çocukları sevdiğim için bu bölümü seçtim \\
\hline Çocuklarla iyi anlaşmak & 19 & Çocuklar ile ilgilenmeyi sevdiğimden seçtim \\
\hline Bu mesleği sevmek & 19 & En sevdiğim meslekti \\
\hline $\begin{array}{l}\text { Kendine uygun meslek } \\
\text { olduğunu düşünmek }\end{array}$ & 18 & $\begin{array}{l}\text { Yapabileceğime inandığım için seçtim Kendime uygun bir } \\
\text { bölüm olduğunu düşündüğ̈̈m için tercih ettim }\end{array}$ \\
\hline $\begin{array}{l}\text { Çocukların gelişimine katkı } \\
\text { sağlamayı istemek }\end{array}$ & 4 & $\begin{array}{l}\text { Çocuklara çok düşkünüm,hayatım boyu onlarla olmak onlara } \\
\text { bir şeyler katmak benim hayalimdi bu hayalime okul öncesi } \\
\text { öğretmenliği bölümünü seçerek adım attım }\end{array}$ \\
\hline $\begin{array}{l}\text { Bilinçli bir anne } \\
\text { ve eş olmak }\end{array}$ & 3 & $\begin{array}{l}\text { İleride aileme de faydalı ve bilinçli bir anne, eş olacağımı } \\
\text { düşündüm }\end{array}$ \\
\hline $\begin{array}{l}\text { Cinsiyetine uygun olduğunu } \\
\text { düşünmek }\end{array}$ & 1 & Bir bayan için uygun bir meslek olduğunu düşündüm \\
\hline Dişsal & 33 & \\
\hline $\begin{array}{l}\text { İş imkanları ve kolay çalışma } \\
\text { şartları }\end{array}$ & 15 & Çalışma şartlarının kolay olması nedeniyle seçtim \\
\hline $\begin{array}{l}\text { Bu bölüm için yeterli puanın ol- } \\
\text { ması }\end{array}$ & 11 & Puanım yeterli gelince seçtim \\
\hline Lisede okunan bölüm & 3 & $\begin{array}{l}\text { Lisede çocuk gelişimi ve eğitimi bölümünü bitirdim ve çok } \\
\text { sevdim universitede de devam ettirmek istedim }\end{array}$ \\
\hline Ailenin isteği & 3 & Ailemin isteği üzerine seçtim \\
\hline Eğlenceli bir bölüm olması & 1 & Ĕ̆lenceli bir bölüm oldŭ̆u için tercih ettim \\
\hline
\end{tabular}

Tablo 2'de öğretmen adaylarının okul öncesi öğretmenlik mesleğini tercih etme nedenleri incelendiğinde, öğretmen adaylarının çoğunun $(\mathrm{f}=89)$ bu mesleği içsel nedenlerle tercih ettiği belirlenmiştir. Bu nedenler içinde ilk sırada çocukları sevmek $(\mathrm{f}=25)$ yer alırken bunu sırasıyla çocuklarla iyi anlaşmak ( $\mathrm{f}=19)$, bu mesleği sevmek ( $\mathrm{f}=19)$, kendine uygun meslek olduğunu düşünmek ( $\mathrm{f}=18$ ), çocukların gelişimine katkı sağlamayı istemek ( $\mathrm{f}=4$ ) ile bilinçli bir anne ve eş olmak ( $\mathrm{f}=3$ ) yer almıştır. Kadın öğretmen adaylarından biri ise cinsiyetine uygun olduğunu düşündüğü için bu mesleği tercih ettiğini belirtmiştir. Öğretmen adaylarının bu mesleği tercih etmelerinde etkili olan dışsal ( $\mathrm{f}=33$ ) nedenler incelendiğinde ise, 
öğretmen adaylarının en çok iş imkanları ve kolay çalışma şartları ( $\mathrm{f}=15)$ ile bu bölüm için yeterli puanının olması $(\mathrm{f}=11)$ nedeniyle tercih ettiği belirlenmiştir. Bunun yanında lisede okunan bölüm ( $f=3)$, ailenin isteği $(f=3)$ ve eğlenceli bir bölüm olması ( $\mathrm{f}=1$ ) okul öncesi öğretmenlik mesleğinini tercih etmelerindeki diğer nedenler olarak yer almıştır.

\section{Okul Öncesi Öğretmenlik Mesleğinin Kadınlar Açısından Avantajları ve Dezavantajlarn}

Öğretmen adaylarının okul öncesi öğretmenlik mesleğinin kadınlar açısından avantajları ve dezavantajlarına yönelik görüşlerine ilişkin bulgular kişisel ve mesleki olarak iki alt kategoriye ayrılmış ve Tablo 3 'te verilmiştir.

Tablo 3. Okul öncesi öğretmenlik mesleğinin kadınlar açısından kişisel \mesleki avantajlarn ve dezavantajları

\begin{tabular}{|c|c|c|}
\hline Avantajlar & $\mathbf{f}$ & Öğretmen Adaylarının Görüşleri \\
\hline Kişisel & 83 & \\
\hline Bilinçli bir anne olma & 57 & Kişisel olarak daha bilinçli bir ebeveyn olabilirim \\
\hline $\begin{array}{l}\text { Çocuklar hakkında daha fazla bilgi } \\
\text { ve deneyim sahibi olma }\end{array}$ & 14 & $\begin{array}{l}\text { İleriki dönemlerde çocuk yetiştirme konusunda daha fazla } \\
\text { bilgi sahibi olabileceğime inanıyorum }\end{array}$ \\
\hline $\begin{array}{l}\text { Mutluluk ve doyum } \\
\text { elde etme }\end{array}$ & 12 & $\begin{array}{l}\text { Hep çocuklarla birlikte rengarenk bir dünya da kalacaksın } \\
\text { Çocukların sınırsız mutluluğundan yararlanmak }\end{array}$ \\
\hline Mesleki & 31 & \\
\hline $\begin{array}{l}\text { Rahat çalışma şartlarına } \\
\text { sahip olma }\end{array}$ & 21 & $\begin{array}{l}\text { Mesleki açıdan da çalışma saatleri özel sektördeki birçok mes- } \\
\text { leğe göre daha uygun }\end{array}$ \\
\hline $\begin{array}{l}\text { Toplumsal cinsiyete } \\
\text { uygun bir meslek yapma }\end{array}$ & 9 & $\begin{array}{l}\text { Kişisel olarak bir bayan için en uygun mesleklerden, yarım } \\
\text { gün çalışır eşiyle de çocuklarıyla da vakit geçirebilir. } 23 \text { yaş } \\
\text { çocuğunu kendiyle okula götürebilir }\end{array}$ \\
\hline $\begin{array}{l}\text { Daha fazla iş } \\
\text { olanağına sahip olma }\end{array}$ & 1 & $\begin{array}{l}\text { Meslek açısından atması iyi ve eğlenceli bir meslek } \\
\text { Ataması kolay, önü açık meslek }\end{array}$ \\
\hline Dezavantajlar & $\mathbf{f}$ & \\
\hline Kişisel & 33 & \\
\hline $\begin{array}{l}\text { Özel hayata olumsuz yansımaların } \\
\text { olması }\end{array}$ & 15 & $\begin{array}{l}\text { Kişisel olarak kendi çocuğumuza pek fazla zaman ayırama- } \\
\text { yacağız }\end{array}$ \\
\hline Aşırı yorgunluk & 14 & $\begin{array}{l}\text { Biraz sabır isteyen yorucu bir meslek olduğunu } \\
\text { düşünüyorum }\end{array}$ \\
\hline Mesleki & 13 & \\
\hline Yipraticı olması & 7 & $\begin{array}{l}\text { Çocuklarla uğraşmak bence zor, bir zaman sonra çok } \\
\text { yıpratıcı olabilir }\end{array}$ \\
\hline Teneffüs saatinin olmaması & 3 & Diğer öğretmenliklere göre teneffüs saati yok \\
\hline Aşırı gürültü & 3 & Aşırı gürültüden rahatsız olunabilir \\
\hline
\end{tabular}


Tablo 3'te öğretmen adaylarının okul öncesi öğretmenlik mesleğinin kadınlar açısından avantajlarına yönelik görüşleri incelendiğinde kişisel avantajlarının ( $\mathrm{f}=83)$ mesleki avantajlarına $(\mathrm{f}=31)$ göre daha fazla olduğunu belirttikleri görülmektedir. Öğretmen adaylarının yarısından fazlasının bu mesleği yapan kadınların bilinçli bir anne olmalarını ( $\mathrm{f}=57$ ) kişisel avantaj olarak değerlendirmişler, bununla birlikte çocuklar hakkında daha fazla bilgi ve deneyim sahibi olma ( $\mathrm{f}=14$ ), mutluluk ve doyum elde etme $(\mathrm{f}=12)$ diğer avantajlar olarak belirtilmiştir. Kadınlar için en önemli mesleki avantaj ise rahat çalışma şartlarına sahip olma $(\mathrm{f}=21)$ olmuştur. Öğretmen adaylarının 9'u toplumsal cinsiyete uygun bir meslek yapmayı ve sadece bir öğretmen adayı da daha fazla iş olanağına sahip olmayı mesleki avantaj olarak belirtmiştir.

Okul öncesi öğretmenlik mesleğinin kadınlar için dezavantajları incelendiğinde ise iş hayatının özel hayata olumsuz yansımalarının olması ( $\mathrm{f}=15$ ) ve aşırı yorgunluk ( $\mathrm{f}=14$ ) kişisel dezavantaj olarak gördükleri belirlenmiştir. Mesleki dezavantajlar ise sırasıyla mesleğin yıpratıcı olması $(\mathrm{f}=7)$, teneffüs saatinin olmaması $(\mathrm{f}=3)$ ve aşırı gürültü $(\mathrm{f}=3)$ olarak belirlenmiştir.

\section{Okul Öncesi Öğretmenlik Mesleğinin Erkekler Açısından Avantajları ve Dezavantajlarn}

Öğretmen adaylarının okul öncesi öğretmenlik mesleğinin erkekler açısından avantajları ve dezavantajlarına yönelik görüşlerine ilişkin bulgular kişisel ve mesleki olarak iki alt kategoriye ayrılmış ve Tablo 4 'te verilmiştir.

Tablo 4'te öğretmen adaylarının okul öncesi öğretmenlik mesleğinin erkekler açısından avantajlarına yönelik görüşleri incelendiğinde, kişisel avantajlarının ( $\mathrm{f}=58)$ mesleki avantajlarına $(\mathrm{f}=13)$ göre daha fazla olduğunu belirttikleri görülmektedir. Öğretmen adaylarının iyi bir baba olma ( $\mathrm{f}=37)$, çocukları iyi tanıma ( $\mathrm{f}=14)$, kendini tanıma ve doğru şekilde ifade etme olanağı bulmayı ( $\mathrm{f}=7$ ) kişisel avantajlar olarak gördükleri belirlenmiştir. Erkekler için en önemli mesleki avantaj ise uygun çalışma şartlarına sahip olmak ( $\mathrm{f}=10)$ olmuştur. Bununla birlikte öğretmen adaylarının 3'ü erkeklerin iyi bir yönetici olabileceklerini belirtmişlerdir. 
Tablo 4. Okul öncesi öğretmenlik mesleğinin erkekler açısından kişisel $\backslash$ mesleki avantajları ve dezavantajları

\begin{tabular}{|c|c|c|}
\hline Avantajlar & $\mathrm{f}$ & Öğretmen Adaylarının Görüşleri \\
\hline Kişisel & 58 & \\
\hline İyi bir baba olma & 37 & İleri de daha tecrübeli bir baba olabilir \\
\hline Çocukları iyi tanımak & 14 & $\begin{array}{l}\text { Çocuğunun gelişimini bilinçli bir şekilde daha yakndan takip } \\
\text { edebilir }\end{array}$ \\
\hline $\begin{array}{l}\text { Kendini tanıma ve doğru şekilde } \\
\text { ifade etme olanağı bulma }\end{array}$ & 7 & $\begin{array}{l}\text { Erkeklerin kadınlara göre daha az sevgilerini gösterebildiğini } \\
\text { düşünüyorum kendilerini bu konuda daha iyi açklayabilirler }\end{array}$ \\
\hline Mesleki & 13 & \\
\hline $\begin{array}{l}\text { Uygun çalışma şartlarına } \\
\text { sahip olma }\end{array}$ & 10 & $\begin{array}{l}\text { Bence bir erkek içinde çok rahat bir meslek yarim gün } \\
\text { çalışacak olursa bir gün içinde başka farkl bir meslekle de } \\
\text { uğraşabilir }\end{array}$ \\
\hline İyi bir yönetici olma & 3 & Merkeziyetçi olurlar ve yönetimleri iyidir \\
\hline Dezavantajlar & f & \\
\hline Kişisel & 29 & \\
\hline $\begin{array}{l}\text { Çocuklarla ilgilenmekte } \quad \text { zor- } \\
\text { lanma }\end{array}$ & 11 & Çocuklarla ilgilenmekte zorlanabilir \\
\hline Sabırlı olmakta zorlanma & 7 & Çocuklara sabır göstermekte zorlanabilir \\
\hline $\begin{array}{l}\text { Kendi çocuğuna daha } \\
\text { az vakit ayırma }\end{array}$ & 5 & $\begin{array}{l}\text { Çok fazla çocukla ilgilendiği için kendi çocuğunu ihmal ede- } \\
\text { bilir }\end{array}$ \\
\hline Meslekten sikılma & 3 & Belirli bir süre sonra sıkılmaya başlar \\
\hline Aşırı yorgunluk & 3 & Çok fazla yorulmaları ve ailesine yansıtması \\
\hline Mesleki & 27 & \\
\hline $\begin{array}{l}\text { Toplumsal cinsiyet açısından } \\
\text { olumsuz bakış açısı }\end{array}$ & 16 & $\begin{array}{l}\text { Toplum açısından garipsenebilir. Çünkü toplum tarafindan } \\
\text { daha çok kadınların yapacağı bir iş olarak algılanıyor }\end{array}$ \\
\hline $\begin{array}{l}\text { Kadın velilerle } \\
\text { yaşanabilecek problemler }\end{array}$ & 6 & $\begin{array}{l}\text { Veliler özellikle anneler öğretmen erkek olduğunda okulla } \\
\text { fazla irtibatta olamıyor. Bu durumda aile ile iş birliğ tam an- } \\
\text { lamıla gerçekleşmemiş oluyor. Bazı ailelerin erkek öğret- } \\
\text { mene güvensizliği olabilir }\end{array}$ \\
\hline $\begin{array}{l}\text { El becerisi gerektiren } \\
\text { işlerde zorlanma }\end{array}$ & 4 & El işi olarak elleri yatkın değilse zor \\
\hline $\begin{array}{l}\text { Toplumsal cinsiyet açısından } \\
\text { çocukların önyargılı olması }\end{array}$ & 1 & $\begin{array}{l}\text { Erkek öğretmenlere karşı bir önyargı vardır. Bu yüzden } \\
\text { çocuklartn erkek öğretmene alısması ve yaklaşması zor } \\
\text { olabilir. Öğretmenle iletişime geçmeyebilir }\end{array}$ \\
\hline
\end{tabular}

Okul öncesi öğretmenlik mesleğinin erkekler için dezavantajları incelendiğinde ise çocuklarla ilgilenmekte zorlanma $(\mathrm{f}=11)$, sabırlı olmakta zorlanma $(\mathrm{f}=7)$, kendi çocuğuna daha az vakit ayırma $(\mathrm{f}=5)$, meslekten sıkılma ( $\mathrm{f}=3$ ) ve aşırı yorgunluğ $(\mathrm{f}=3)$ en önemli kişisel dezavantaj olarak gördükleri belirlenmiştir. Mesleki dezavantajlar ise sırasıyla toplumsal cinsiyet açısından olumsuz bakış açısı $(\mathrm{f}=16)$, kadın velilerle yaşanabilecek problemler $(f=6)$, el becerisi gerektiren işlerde zorlanma $(f=4)$ ve 
toplumsal cinsiyet açısından çocukların önyargılı olması ( $\mathrm{f}=1)$ olarak gördükleri belirlenmiştir.

\section{Okul Öncesi Ĕ̆itimde Öğretmenin Cinsiyetinin Mesleki Yeterliliğe Etkisi}

Öğretmen adaylarının okul öncesi eğitimde öğretmenin cinsiyetin mesleki yeterliliği etkisine yönelik görüşlerine ilişkin bulgular Tablo 5'de verilmiştir.

Tablo 5. Cinsiyetinin mesleki yeterliliğe etkisi

\begin{tabular}{lll}
\hline Mesleki Yeterlilik & f & Öğretmen Adaylarının Görüşleri \\
\hline $\begin{array}{l}\text { Kadın ve erkek } \\
\text { öğretmenler }\end{array}$ & 49 & $\begin{array}{l}\text { Kendini eğitmiş kadın ve erkeğin verimli olacă̆ımı düşünüyorum } \\
\text { Öğretmenin verdiği eğitime bağlıdır erkek veya kadın olması fark et- } \\
\text { mez Topluma faydalı bireyler yetişecek kişinin cinsiyeti çokta önemli } \\
\text { değildir }\end{array}$ \\
\hline Kadın öğretmenler & 36 & $\begin{array}{l}\text { Çocuklar daha çok annelerine bağlı oldukları için mesleğinde iyi bir } \\
\text { kadın daha verimli olabilir }\end{array}$ \\
\hline Erkek öğretmenler & 4 & $\begin{array}{l}\text { Erkek öğretmen daha verimlidir. Çünkü erkek okul öncesi öğretmeni } \\
\text { işine daha sadık ve işinin en iyisini yapıyor diye düşünüyorum }\end{array}$ \\
\hline
\end{tabular}

Tablo 5 incelendiğinde, öğretmen adaylarının 49'u hem kadın hemde erkek öğretmenlerin okul öncesi öğretmenlik mesleğinde yeterli olabileceğini düşünürken, 36'sı bu meslekte kadınların daha yeterli olacağını ve 4 'ü de erkelerin daha yeterli olacağını düşündüklerini belirtmişlerdir.

\section{Toplumsal Cinsiyet Açısından Toplumun Okul Öncesi Öğretmenliğine Bakış Açısı}

Öğretmen adaylarının toplumsal cinsiyet açısından toplumun okul öncesi öğretmenliğine bakış açısına yönelik görüşlerine ilişkin bulgular Tablo 6 'da verilmiştir.

Tablo 6 incelendiğinde öğretmen adaylarının 83'ü toplumun okul öncesi öğretmenlik mesleğine bakış açısının olumsuz olduğunu düşünürken, sadece $10^{\prime}$ u toplumun olumlu bakış açısına sahip olduğunu düşündüklerini belirtmişlerdir. 
Tablo 6. Toplumun okul öncesi öğretmenliğine bakış açısı

\begin{tabular}{lrl}
\hline Bakış Açısı & $\mathbf{f}$ & Öğretmen Adaylarının Görüşleri \\
\hline Olumsuz & $\mathbf{8 3}$ & \\
\hline Çocuk bakıcısı & 39 & $\begin{array}{l}\text { Okul öncesi okuduğumu söylediğimde çocuğa mı ba- } \\
\text { kacaksın, bakıcı mı olacaksın gibi söylemler olması okul } \\
\text { öncesine bakış açısının çocuğa eğitim veren yerden çok } \\
\text { bakılan yer gibi düşündürüyor }\end{array}$ \\
\hline Kolay meslek & 25 & $\begin{array}{l}\text { Çok fazla değer verilen bir meslek olduğunu } \\
\text { düşünmüyorum. Toplum genellikle basit bir meslek } \\
\text { olduğunu düşünüyor }\end{array}$ \\
\hline Gereksiz meslek & 14 & Zaman kaybı olduğunu düşünüyorlar \\
\hline Kadınlara göre bir meslek & 5 & Sadece bayan öğretmenler çalışabilir sanılıyor \\
\hline Olumlu & $\mathbf{1 0}$ & \\
\hline Gerekli ve önemli meslek & 10 & Güzel ve iyi bir meslek olarak görüyorlar \\
\hline
\end{tabular}

Olumsuz bakış açısının nedenlerini ise bu mesleğin daha çok çocuk bakıcısı ( $\mathrm{f}=39$ ) olarak görülmesi, kolay $(\mathrm{f}=25)$ ve gereksiz bir meslek $(\mathrm{f}=14)$ olduğunun düşünülmesi ve kadınlara uygun bir meslek $(\mathrm{f}=5)$ olarak algılanması olarak belirtmişlerdir.

\section{Toplumsal Cinsiyet Algılarına Göre Okul Öncesi Öğretmenlik Mes- leğinin Öğretmen Adaylarına Uygunluğu}

Öğretmen adaylarının toplumsal cinsiyet algılarına göre okul öncesi öğretmenlik mesleğinin kendilerine uygunluğuna yönelik görüşlerine ilişkin bulgular Tablo 7'de verilmiştir.

Tablo 7'de öğretmen adaylarının toplumsal cinsiyet algılarına göre okul öncesi öğretmenlik mesleğinin kendilerine uygunluğuna yönelik görüşleri incelendiğinde, öğretmen adaylarının 89'u okul öncesi öğretmenlik mesleğinin kendilerine uygun olduğunu düşündükleri, bunun yanında 8'inin kendisine uygun bir meslek olmadığını düşündükleri belirlenmiştir. Öğretmen adaylarının kendilerine uygun olduğunu düşünme nedenleri arasında, çocukları sevme ( $\mathrm{f}=39)$, çocuklarla anlaşma $(\mathrm{f}=19)$, iyi bir öğretmen olacağına inanma $(\mathrm{f}=16)$, kişiliğine $(\mathrm{f}=14)$ ve cinsiyetine $(\mathrm{f}=1)$ uygun bir meslek olduğunu düşünme yer almıştır. 
Öğretmen Adaylarının Toplumsal Cinsiyet Algılarına Göre Okul Öncesi Öğretmenliğine İlişkin Görüşleri

Tablo 7. Toplumsal cinsiyet algılarna göre okul öncesi öğretmenlik mesleğinin öğretmen adaylarına uygunluğu

\begin{tabular}{|c|c|c|}
\hline Görüşler & $\mathbf{f}$ & Öğretmen Adaylarının Görüşleri \\
\hline Uygun & 89 & \\
\hline Çocukları seviyorum & 39 & $\begin{array}{l}\text { Evet düşünüyorum. Çocuklarla ilgiyle ve şefkatle } \\
\text { yakınlaşacağıma inandığım için bu mesleği seçtim }\end{array}$ \\
\hline Çocuklarla anlaşabiliyorum & 19 & Çocuklarla vakit geçirmekten kolay kolay sıkılmam \\
\hline $\begin{array}{l}\text { İyi bir öğretmen } \\
\text { olacağıma inanıyorum }\end{array}$ & 16 & $\begin{array}{l}\text { Uygun olduğunu düşünüyorum. Çünkü bu alanla ilgili } \\
\text { araştırmayı yenilikleri severek takip ediyorum, çocuklar için bir } \\
\text { şeyler yapmayı seviyorum }\end{array}$ \\
\hline $\begin{array}{l}\text { Kişiliğime uygun bir meslek } \\
\text { olduğunu düşünüyorum }\end{array}$ & 14 & Evet, kişilik özelliklerime uygun olduğunu düşünüyorum \\
\hline $\begin{array}{l}\text { Cinsiyetime uygun bir meslek } \\
\text { olduğunu düşünüyorum }\end{array}$ & 1 & Evet bir kadın için ideal bir meslek \\
\hline Uygun değil & 8 & \\
\hline İstediğim bölüm değil & 3 & $\begin{array}{l}\text { Bana uygun olduğunu düşünmüyorum çok tercih ettiğim bir } \\
\text { bölüm değildi }\end{array}$ \\
\hline Çok fazla sorumluluk var & 2 & $\begin{array}{l}\text { Çocukları severim ama aşırı ilgilenmek hele ki tüm gelişim alan- } \\
\text { larımı takip etmek, planlar ve etkinlik programları hazırlamak } \\
\text { bana zor geliyor }\end{array}$ \\
\hline $\begin{array}{l}\text { Çocuklarla iletişim } \quad \mathrm{ku}- \\
\text { ramiyorum }\end{array}$ & 1 & Uygun değil, çünkü her çocukla iletişime geçemiyorum \\
\hline Sabırlı değilim & 1 & Sabırlı değilim \\
\hline $\begin{array}{l}\text { Çocuklarla uzun süre zaman } \\
\text { geçiremiyorum }\end{array}$ & 1 & Uzun bir süre sonra çocuklarla vakit geçirmek zor geliyor \\
\hline
\end{tabular}

Kendilerine uygun bir meslek olmadığını düşünen öğretmen adayları ise uygun olmama nedenlerini, istediğim bölüm değil ( $f=3)$, çok fazla sorumluluk var $(\mathrm{f}=2)$, çocuklarla iletişim kuramıyorum $(\mathrm{f}=1)$, sabırlı deği$\lim (\mathrm{f}=1)$ ve çocuklarla uzun süre zaman geçiremiyorum $(\mathrm{f}=1)$ olarak belirtmişlerdir.

\section{Tartışma}

\section{Öğretmen Adaylarının Okul Öncesi Öğretmenlik Mesleğini Tercih Etme Nedenleri}

Araştırma sonuçları incelendiğinde, öğretmen adaylarının okul öncesi öğretmenliği bölümünü tercih etmelerinde içsel ve dışşsal nedenler etkili olmakla birlikte içsel nedenlerin tercihte öne çıtığı belirlenmiştir. Öğretmen adayları daha çok çocukları sevme ve onlarla iyi anlaşma, bu mesleği 
sevme, kendine ve cinsiyetine uygun olduğunu düşünme gibi içsel nedenlerle bu mesleği tercih ederken, iş imkanları ve kolay çalışma şartları ile bu bölüm için yeterli puanlarının olması da bu mesleği tercih etmelerindeki en önemli dışsal nedenler olmuştur. Okul öncesi öğretmenliği gibi küçük yaş grubu ile çalışacak olan öğretmen adaylarının çocukları sevmek ve onlarla iyi anlaşmak gibi nedenlerle bu mesleği tercih etmeleri oldukça önemli olarak değerlendirilebilir. Bununla birlikte öğretmen adaylarının iş garantisi olduğunu düşündükleri bir bölüm seçmeleri de beklenen bir sonuç olarak görülebilir. Aksu (2016) da benzer şekilde, eğitim fakültesinde öğrenim gören öğrencilerin bölümleri hakkındaki görüşleri belirlemek amacıyla yaptığı araştırma sonucunda eğitim fakültesine gelen bireylerin bölüm seçmelerinde bireysel etmenlerin, çevresel etmenlere (aile, öğretmen ve arkadaş çevresi, bölümün iş olanakları vb.) oranla daha yüksek olduğunu belirlemiştir. Aslan ve Akyol (2006), okul öncesi öğretmen adaylarının öğretmenlik mesleğini tercih nedenleri arasında ailelerinde öğretmen olan bireylerin bulunması, ailenin şartlandırması, iş garantisi ve öğretmen olma isteği gibi tercih nedenleri belirten öğrencilerin öğretmenlik mesleğine ilişkin olumlu tutum sergilediklerini belirlemişlerdir. Aktürk (2012), öğretmen adaylarının öğretmenlik mesleğini tercih etme nedenleri ile öğrenmeye ilişkin tutumlarını incelediği araştırma sonucunda, genel olarak öğretmenlik mesleğini içsel nedenlerin etkisi ile tercih eden öğretmen adaylarının öğrenmeye daha açık, öğrenmeye ilişkin beklentilerinin daha yüksek düzeyde ve öğrenmeye ilişkin kaygılarının ise daha düşük düzeyde olduğunu belirlemiştir. Buldur ve Bursal (2015) da, öğretmen adaylarının meslek tercih nedenlerinin özgeci, içsel ve dışsal faktörler şeklinde sıralandığını ve öğretmen adaylarının gelecek beklentilerinin genellikle olumlu olduğunu belirlemişlerdir. Bu araştırma sonuçları öğretmen adaylarının mesleki tercih nedenlerini belirlemeye yönelik yapılan diğer araştırma sonucuyla tutarlılık göstermektedir.

\section{Okul Öncesi Öğretmenlik Mesleğinin Kadınlar-Erkekler Açısından Avantajlarn ve Dezavantajlar}

Öğretmen adaylarına göre, okul öncesi öğretmenlik mesleğinin kadınlar açısından en önemli kişisel avantajı bilinçli bir anne olmakken, mesleki 
avantajı da rahat çalışma şartlarına sahip olmak olarak belirtilmiştir. Öğretmen adaylarının kendi çocuklarını sahip oldukları bilgilerle doğru bir şekilde yetiştirebileceklerini ve yarım gün çalışma, yaz tatili gibi rahat çalışma şartları nedeniyle bir kadın olarak rahat edebileceklerini düşündükleri belirlenmiştir. Aşırı yorgunluk ve duygusallık gibi durumlar ve bunların özel hayatlarına yansımasının yanında mesleğin yıpratıcı olmasının da kadın öğretmenler için dezavantaj olarak görüldüğü belirlenmiştir. Öğretmen adaylarına göre, okul öncesi öğretmenlik mesleğinin erkekler açısından en önemli kişisel avantajı iyi bir baba olmakken, mesleki avantajı da uygun çalışma şartlarına sahip olmak olmuştur. Bu mesleğin erkekler için en önemli kişisel dezavantajının çocuklarla ilgilenmekte zorlukken, en önemli mesleki dezavantajının da toplumsal cinsiyet açısından olumsuz bakış açısına maruz kalmak olarak gördükleri belirlenmiştir. Öğretmenliğin kadınlar tarafından daha çok tercih edilmesi ve bu nedenle "kadın mesleği" olarak görülmesi, meslek seçimi ile ilgili ön yargılar ve küçük çocuklarla çalışmayı seçme konusunda yaşanan olumsuzluklarla ilgili sonuçlar çeşitli araştırmalarla da (Johnston, McKeown ve McEwen, 1999; Saban, 2003; Smedley, 2007) ortaya konmuştur. Bununla birlikte öğretmen adayları erkek okul öncesi öğretmenlerinin kadın velilerle problem yaşayabileceğini ve çocukların toplumsal cinsiyet açısından erkek öğretmene yaklaşmakta zorlanabileceğini düşündükleri belirlenmiştir. Öğretmen adaylarının bu düşünceleri, okul öncesi eğitimde daha çok annelerin etkin olması, veli katılım etkinlikleri yada veli toplantılarına daha çok kadın velilerin katılmasından kaynaklanmış olabilir. Gürşimşek, Kefi ve Girgin (2007), yaptıkları araştırma sonucunda babaların geleneksel rollerinden çıkarak eğitime katılımlarının desteklenmesinin çocuğun gelişim gereksinimlerinin karşılanması açısından önemli olduğunu ortaya koymuşlardır.

\section{Okul Öncesi Ĕ̆itimde Öğretmenin Cinsiyetinin Mesleki Yeterliliğe Etkisi}

Okul öncesi eğitimde öğretmenin cinsiyetinin mesleki yeterliliğe etkisine ilişkin öğretmen adaylarının görüşleri incelendiğinde, öğretmen adaylarının çoğunun cinsiyetin mesleği yeterliliğe etkisinin olmadığını düşündükleri, bununla birlikte kadınların okul öncesi öğretmenlik mesleğinde daha yeterli olduklarını düşünenlerin oranın da oldukça yüksek 
olduğu belirlenmiştir. Bu mesleğin, annelik içgüdüsü ile bağdaştırılması ve kadınların şefkat, merhamet, sabır gibi kişilik özelliklerine daha fazla sahip olduklarını düşünmeleri okul öncesi öğretmenliğinin kadın mesleği olarak algılanmasına neden olmuş olabilir. Yalçın, Yalçın ve Macun (2017) da, okul öncesi öğretmenliği açısından öğretmenin, mesleki bilgi ve becerisinin cinsiyetinden daha önemli olduğu, etkinlik seçiminde cinsiyetin bir etkisi olmadığı sonuçlarına ulaşmışlardır. Aynı araştırmada, okul öncesi öğretmenliği açısından öğretmenin cinsiyetinin çocukla iletişim kurmada önemli ve etkili olduğu, bayanların çocuklara daha samimi ve içten yaklaşabildikleri sonuçlarına ulaşmışlardır. $\mathrm{Bu}$ sonuçlar araştırma sonuçlarıyla tutarlılık göstermektedir.

\section{Toplumsal Cinsiyet Açısından Toplumun Okul Öncesi Öğretmenliğine Bakış Açısı}

Toplumsal cinsiyet açısından toplumun okul öncesi öğretmenliğine bakış açısına yönelik öğretmen adaylarının görüşleri incelendiğinde, öğretmen adaylarının çoğunun toplumsal cinsiyet açısından toplumun okul öncesi öğretmenlik mesleğine bakış açısının olumsuz olduğunu düşündükleri belirlenmiştir. Olumsuz bakış açısının bu mesleğin daha çok çocuk bakıcılığı olarak görülmesi, kolay ve gereksiz bir meslek olduğunun düşünülmesi ve kadınlara uygun bir meslek olarak algılanması gibi nedenlerden kaynaklandığı belirtilmiştir. Ünsal ve Bağçeci (2016) de, öğretmenlerin mesleki imajlarını inceledikleri araştırma sonucunda, katılımcıların öğretmenlik mesleğinin statüsünü ve saygınlığını düşük olarak değerlendirdiklerini belirlemişlerdir.

\section{Toplumsal Cinsiyet Algılarna Göre Okul Öncesi Öğretmenlik Mesleğinin Öğretmen Adaylarna Uygunluğu}

Öğretmen adaylarının toplumsal cinsiyet algılarına göre okul öncesi öğretmenlik mesleğinin kendilerine uygunluğuna yönelik görüşleri değerlendirildiğinde de, öğretmen adaylarının çoğunluğunun okul öncesi öğretmenlik mesleğinin kendilerine uygun olduğunu düşündükleri, bunun yanında küçük bir bölümünün ise kendilerine uygun bir meslek 
olmadığını düşündükleri belirlenmiştir. Öğretmen adaylarının kendilerine uygun bir meslek olduğunu düşünme nedenleri arasında da en çok çocukları sevmek, çocuklarla anlaşmak ve iyi bir öğretmen olacağına inanmak yer almıştır. Durmuşçelebi, Yıldız ve Saygı (2017) yaptıkları araştırma sonucunda, öğretmen adaylarının öğretmenlik mesleğini sevmeleri ve kendilerini bu mesleğe uygun görmeleri ile öğretmen adaylarının cinsiyetleri arasında farklılık olduğunu, kadın öğretmen adaylarının öğretmenlik mesleğine kendilerini daha yakın buldukları ve erkek adaylara oranla mesleği daha çok sevdiklerini belirlemişlerdir. Öngen ve Aytaç (2013)'da yaptıkları araştırmada, üniversite öğrencilerin toplumsal cinsiyet rollerine ilişkin farklı tutum içinde olduklarını, kızların erkeklere nazaran daha eşitlikçi tutum ve rollere sahipken, erkeklerin daha geleneksel cinsiyet rollerine sahip olduklarını belirlemişlerdir.

\section{Sonuç}

Sonuç olarak okul öncesi öğretmen adaylarının meslekleri ile ilgili bazı cinsiyetçi kalıp yargılara sahip olmakla birlikte, genel olarak mesleğe ve toplumsal cinsiyet rollerine karşı olumlu bir yaklaşım sergiledikleri söylenebilir. Okul öncesi öğretmenliği gibi alanlarda daha çok kadınların olması ve kadınların bu iş için uygun kişiler olduklarının düşünülmesi gibi kalıplaşmış cinsiyet rollerine karşı toplumsal duyarlılığın artırılması, bunun için de alanda çalışan erkek öğretmen sayısının daha da artırılarak toplumsal cinsiyet eşitliğinin sağlanması gerekmektedir. Öğretmen yetiştirme programlarına yönelik yanlış algıların (kolay meslek, kadın mesleği gibi) daha tutarlı algılara dönüştürülerek, tüm öğrencilerin pozitif cinsiyet kimlikleri geliştirmelerinin desteklenmesi önemli görülmektedir. Okul öncesi dönem çocuklarının yaşamında önemli bir yeri olan öğretmenlerin çocuklara karşı olan tutum ve davranışları, onlar için rol model olmaları, çocukların mesleklere ve bu meslekleri yapan kişilere olan bakış açısını etkileyecektir. Bu nedenle öğretmen adaylarına toplumsal cinsiyet eşitliğine dönük duyarlılık ve farkındalık kazandırmak için öğretmen yetiştiren programlara toplumsal cinsiyet derslerinin konulması, erkek öğretmen adayları için yeni stratejiler üretilerek mesleki algılarının olumsuzdan olumluya dönüştürülmesi sağlanabilir. 


\title{
EXTENDED ABSTRACT
}

\section{Teacher Candidates' Views on Preschool Teaching According to Social Gender Perceptions}

\author{
Sema Öngören
}

Hacı Bektas Veli University

Gender is used to describe the biological aspect of being male and female. Gender roles are sets of expectations about how women and men should think, act and feel. Social gender points out to social and psychological aspects of gender. Social gender, which is a concept about how the society see us as woman or man, how society perceives us, what it thinks about us and what it expects us in our behaviors, is at the same time identifying yourself as a woman or a man. In all societies, there are a number of behaviors, attitudes, rights, duties and obligations that are deemed appropriate for male and female roles. Women are perceived as more sensitive, relevant, caring and so on, and expected to be a housewife, teacher, nurse etc. while men are perceived as independent, dashing, strong and so on and they are expected to be soldier, engineer, trader etc. that all these are because of gender differences. Therefore, the manner, rate, representation, visibility and occupational preferences of women and men in social life are affected by the gender perception that is valid in a society. One of the most important phenomena that shape the life of the individual is job preference. It is important that teacher candidates who take an active role in the training of qualified manpower and socialization of individuals have a positive attitude towards their preferred professions, and that they do their jobs with pleasure. It is the first step of being a qualified teacher when it comes to gender-perception in teaching professions, and it is especially important for women such as preschool teachers to be trained in a field that is more suitable for women. This research has been conducted to examine the opinions of teacher candidates on preschool teaching profession according to gender perceptions. In this context, the sub-objectives of the research are determined as the reasons for choosing preschool teaching 
profession, the advantages and disadvantages of preschool teaching profession for women and men, the effect of gender of teacher on preschool teaching professional competence, the perspective of the society on preschool teaching in terms of gender and the perception of preschool teaching profession in terms of gender.

\section{Method}

The research has been conducted in accordance with the case study pattern of qualitative research methods. The study group of the study consisted of 105 preschool teacher candidates from Preschool Education Department of Education Faculty at Nevsehir Haci Bektas Veli University. Semi-structured interview form consisting of seven open-ended questions have been used in order to collect the research data. Content analysis method has been used to analyze the data obtained from the interview form.

\section{Findings and Result}

When the results of the research are evaluated, it is seen that the teacher candidates prefer preschool teaching department because of internal and external reasons. While teacher candidates have preferred this profession for internal reasons such as loving children and having a good deal with them and thinking that they are suitable for themselves and their gender, job opportunities and easy work conditions have been the most important external reasons for them to choose this profession. According to teacher candidates, the most important personal advantage of the preschool teaching profession in terms of women and men is stated as being a conscious parent, while the professional advantage is stated as having comfortable work conditions. It has been determined that teacher candidates perceive the most important personal disadvantage of this profession for male as the difficulty in dealing with children and the most important occupational disadvantage as a negative point of view in terms of gender. When the opinions of teacher candidates about the effect of gender of teachers on preschool teaching are evaluated, it is determined that most of the teacher candidates thin that gender do not have any effect on professional 
competence; after all, it is determined that the rate of people who think that women are more adequate in the preschool teaching profession is also quite high. As a result of the research, it is determined that while most of the teacher candidates think preschool teaching is a suitable profession for themselves, a few of them think it is not the right profession for them. As a result, preschool teacher candidates have some gendered stereotypes about their professions, but they generally have a positive attitude towards this profession and gender roles. The social sensitivity towards stereotypical gender roles, such as the fact that there should be more women in the fields such as preschool teaching, and women are suitable people for this job, should be increased, gender equality should be ensured by increasing the number of male teachers working in the field. It is considered important to support the development of positive gender identities for all students by converting false perceptions of teacher training programs (such as easy occupation, women's profession) into more consistent perceptions. The attitudes and behaviors of the teachers who have an important place in the life of preschool children, their being role models for them will affect the perspective of the children towards teachers and professions. For this reason, it is possible to give social gender courses in teacher training programs in order to make teacher candidates gain sensitiveness and awareness, and also new strategies can be developed for male teacher candidates to convert their negative professional perceptions into positive.

\section{Kaynakça / References}

Altınova, H.H. ve Duyan, V. (2013). Toplumsal cinsiyet algısı ölçeğinin geçerlik ve güvenirlik çalışması. Toplum ve Sosyal Hizmet Dergisi, $24(2), 9-22$.

Aksu, H.H. (2016). Eğitim fakültesinde öğrenim gören öğrencilerin bölümleri hakkındaki görüşleri: Giresun Üniversitesi örneği. Kastamonu Eğitim Dergisi, 24 (1), 299-316.

Aktürk, A.O. (2012). Öğretmen adaylarının öğrenmeye ilişkin tutumlarının öğretmenlik mesleğini tercih etme nedenlerine ve akademik başarılarına göre incelenmesi. Ahi Evran Üniversitesi Kırşehir Eğitim Fakültesi Dergisi, 13 (3), 283-297. 
Aslan ve Akyol (2006). Okul öncesi öğretmen adaylarının öğretmenlik mesleğine yönelik tutumları ve mesleki benlik saygılarının incelenmesi. Ç.Ü. Sosyal Bilimler Enstitüsü Dergisi, 15 (2), 51-60.

Ayan, S. (2014). Cinsiyetçilik: Çelişik duygulu cinsiyetçilik. Cumhuriyet Tıp Dergisi, 36, 147-156.

Ayık, A. ve Ataş, Ö. (2014). Öğretmen adaylarının öğretmenlik mesleğine yönelik tutumları ile öğretme motivasyonları arasındaki ilişki. Eğitim Bilimleri Araştırmaları Dergisi, 4(1), 25-43.

Balat U., G., Bilgin, H. ve Ünsal, F.Ö. (2017). Okul öncesi öğretmenlerinin öğretmenlik tutumları ve sınıf yönetimleri arasındaki ilişkinin incelenmesi. Eğitim ve Toplum Araştırmaları Dergisi, 4(1), 114-126.

Buldur, S. ve Bursal, M. (2015). Fen bilgisi öğretmen adaylarının meslek tercih nedenlerinin etki düzeyleri ve mesleki geleceklerine yönelik beklentileri. Necatibey Eğitim Fakültesi Elektronik Fen ve Matematik Ĕ̈itimi Dergisi, 9 (1), 81-107.

Bee, H. ve Boyd, D. (2009). Çocuk gelişim psikolojisi. (O. Gündüz Çev.). İstanbul: Kaknüs.

Berk, L.E. (2013). Bebekler ve çocuklar doğum öncesinden orta çocukluğa. (7. Bsm). (N. Işıkoğlu Erdoğan Çev. Ed.). Ankara: Nobel.

Bozdoğan, A.E., Aydın, D. ve Yıldırım, K. (2007). Öğretmen adaylarının öğretmenlik mesleğine ilişkin tutumları. Ahi Evran Üniversitesi Kırşehir Ĕ̆itim Fakültesi Dergisi, 8 (2), 83-97.

Çetin, B. (2012). İlköğretim öğretmen adaylarının profillerinin çeşitli değişkenler açısından incelenmesi. İlköğretim Online, 11(3), 596610.

Çermik, H., Doğan, B., ve Şahin, A. (2010). Sınıf öğretmenliği öğretmen adaylarının öğretmenlik mesleğini tercih sebepleri. Pamukkale Üniversitesi Eğitim Fakültesi Dergisi, 28, 201-212.

Coştu, B. (2011). Bir meslek olarak öğretmenlik. (A. R. Akdeniz ve M. Küçük Edt.). Ĕ̆itim Bilimine Giriş. Ankara: Nobel.

Dökmen, Z.Y. (2009). Toplumsal cinsiyet. İstanbul: Remzi Kitabevi.

Durmuşçelebi, M., Yıldız, N. ve Saygı, E. (2017). Öğretmen adaylarının öğretmenlik mesleğine ilişkin tutumlarının bazı değişkenler açısından incelenmesi. OPUS-Uluslararası Toplum Araştırmaları Dergisi, 7 (12), 8-32. 
Ekici, F. Y. (2014). Öğretmen adaylarının öğretmenlik mesleğine yönelik tutumlarının çeşitli değişkenler açısından incelenmesi:İstanbul Sabahattin Zaim üniversitesi örneği. Uluslararası Sosyal Araştırmalar Dergisi, 7(35), 658-665.

Ekinci, N. (2017). Öğretmen adaylarının öğretmenlik mesleği ve alan seçiminde etkili olan motivasyonel etkenler. İlköğretim Online, 16(2), 394-405.

Esen, Y. (2013). Hizmet öncesi öğretmen eğitiminde toplumsal cinsiyet duyarlılığını geliştirme amaçlı bir çalışma. Ĕ̆itim ve Bilim, 38 (169), 280-295.

Gürşimşek, I. , Kefi, S. ve Girgin, G. (2007). Okulöncesi eğitime babaların katılım düzeyi ile ilişkili değişkenlerin incelenmesi. Hacettepe Üniversitesi Eğitim Fakültesi Dergisi, 33, 181-191.

Gökçe, F. ve Sezer, G. O. (2012). Öğretmen adaylarının öğretmenlik mesleğine yönelik tutumları:Uludağ üniversitesi örneği. Uludă̆ Üniversitesi Eğitim Fakültesi Dergisi, 25(1), 1-23.

Johnston, J., McKeown, E., ve McEwen, A. (1999). Choosing primary teaching as a career: The perspectives of males and females in training. Journal of Education for Teaching, 25(1), 55-64. doi: 10.1080/02607479919673

Kızıltaş, E., Halmatov, M. ve Sarıçam, H. (2012). Okul öncesi öğretmenliği öğrencilerinin öğretmenlik mesleğine yönelik tutumları. Mehmet Akif Ersoy Üniversitesi Eğitim Fakültesi Dergisi, 12 (23), 173 - 189.

Mulholland, J. ve Hansen, P. (2003) Men who become primary school teachers: An early portrait. Asia-Pacific Journal of Teacher Education, 31 (3), 213-224. doi: 10.1080/0955236032000149355

Öngen, B. ve Aytaç, S. (2013). Üniversite öğrencilerinin toplumsal cinsiyet rollerine ilişkin tutumları ve yaşam değerleri ilişkisi. Sosyoloji Konferanslarl, 48, 1-18

Özbek, R., Kahyaoğlu, M. ve Özgen, N. (2007). Öğretmen adaylarinin öğretmenlik mesleğine yönelik görüşlerinin değerlendirilmesi. Sosyal Bilimler Dergisi, IX (2), 221- 232.

Özyurt, B.E. (2014). Cinsiyet. (Y. Kuzgun ve D. Deryakulu Ed.). Eğitimde Bireysel Farklllkklar, Ankara: Nobel. 
Saban, A. (2003). A Turkish profile of prospective elementary school teachers and their views of teaching. Teaching and Teacher Education, 19, 829-846.

Santrock, J.W. (2012). Yaşam boyu gelişim. (G. Yüksel Çev. Ed.). Ankara: Nobel.

Smedley, S. (2007). Learning to be a primary school teacher: reading one man's story. Gender and Education, 19(3), 369-385.

Terzi, A. ve Tezci, E. (2007). Necatibey Eğitim Fakültesi öğrencilerinin öğretmenlik mesleğine ilişkin tutumları. Kuram ve Uygulamada Ĕ̆itim Yönetimi (52), 593-614.

Trawick-Smith, J. (2014). Erken çocukluk döneminde gelişim:Çok Kültürlü Bir Bakış Açısı. (B. Akman Çev. Ed.). Ankara: Nobel.

Ünsal, S., ve Bağçeci, B. (2016). Öğretmenlerin mesleki imajlarina ilişkin görüssleri ve mesleki imaja etki eden faktörler. Journal of Human Sciences, 13(3), 3905-3926. doi:10.14687/jhs.v13i3.3908

Üstün, E., Erkan, S. ve Akman, B. (2004). Türkiye'de okulöncesi öğretmenliği öğrencilerinin öğretmenlik mesleğine yönelik tutumlarının incelenmesi. Kırgızistan-Türkiye Manas Üniversitesi Sosyal Bilimler Dergisi, 5 (10), 129-136.

Woolfolk-Hoy, A. (2010). Eğitim psikolojisi. (D. Özen Çev.). İstanbul: Kaknüs Yayınları.

Yalçın, F., Yalçın, M. ve Macun, B. (2017). Okul öncesi öğretmenlerinin okul öncesi eğitimde öğretmen cinsiyeti ile ilgili görüşleri. Bayburt Eğitim Fakültesi Dergisi, 12 (24), 693-710.

Zencirkıran, M. (2016). Sosyoloji. Bursa: Dora.

\section{Kaynakça Bilgisi / Citation Information}

Öngören, S. (2019). Öğretmen adaylarının toplumsal cinsiyet algılarına göre okul öncesi öğretmenliğine ilişkin görüşleri.OPUSUluslararası Toplum Araştırmaları Dergisi, 11(18), 1733-1796. DOI: 10.26466/opus.516102. 